\title{
RESPONSE OF MICROALGAE IN A CHANGING CLIMATE AND ENVIRONMENT
}

\author{
Wai-Kuan Yong, Yong-Hao Tan, Sze-Wan Poong, and Phaik-Eem Lim* \\ Institute of Ocean and Earth Sciences, University of Malaya, 50603 Kuala Lumpur, Malaysia \\ *Corresponding author: phaikeem@um.edu.my \\ Received: 23 Nov 2016. Revised: 28 Nov $2016 \quad$ Accepted: 28 November 2016
}

\begin{abstract}
Microalgae are ecologically important as a major primary productivity driver via photosynthetic carbon fixation. As the primary producers and food sources for higher trophic organisms, microalgae play a crucial role in maintaining the equilibrium of food webs in the aquatic ecosystem. The current shifts of global climate due to anthropogenic release of greenhouse gases have been reported to pose numerous impacts on microalgae. Extreme fluctuations in atmospheric temperature, light intensity, ultraviolet (UV) radiations, carbon dioxide $\left(\mathrm{CO}_{2}\right)$ levels, and salinity can lead to alterations in growth, disruption of homeostasis, photosynthetic rate, respiration, enzymatic activity, protection to oxidative damage, and trophic transfer in microalgae. Various studies on microalgal responses to these environmental changes are ongoing to provide a deeper insight into the relationship between microalgal growth, metabolic adjustment and community structure. In this review the authors aim to highlight the recent findings on the responses of microalgae in the changing environment.

Abstrak Mikroalga adalah penting dari segi ekologi sebagai penggerak produktiviti utama melalui penetapan karbon secara fotosintetik. Sebagai pengeluar primer dan sumber makanan kepada organisma trofik tinggi, mikroalga memainkan peranan penting dalam mengekalkan keseimbangan siratan makanan dalam ekosistem akuatik. Perubahan iklim global akibat penghasilan gas-gas rumah hijau oleh manusia telah dilaporkan memberi pelbagai impak kepada mikroalga. Perubahan suhu atmosfera, keamatan cahaya, sinaran ultraungu (UV), paras karbon dioksida, dan kemasinan yang ketara akan membawa perubahan kepada pertumbuhan, gangguan kepada homeostasis, kadar fotosintesis, respirasi, aktiviti enzim, perlindungan daripada kerosakan oksidatif dan pemindahan trofik dalam mikroalga. Pelbagai kajian mengenai tindakbalas mikroalga terhadap perubahan alam sekitar sedang dijalankan bagi memberi pandangan yang lebih mendalam terhadap hubungan antara pertumbuhan, pelarasan metabolik dan struktur komuniti mikroalga. Dalam ulasan ini penulis-penulis akan menampilkan hasil kajian terkini mengenai tindak balas mikroalga dalam persekitaran yang kian berubah.
\end{abstract}

Keywords: microalgae, climate change, environmental factors

\section{INTRODUCTION}

Microalgae are photosynthetic organisms inhabiting a highly diverse range of habitats from sea ice, sea waters, snow, inland waters to soil. Besides being primary producers in food chains, microalgae are sources of useful biomaterials for biotechnological applications and commercial interests (Milledge, 2011). Microalgal growth is highly dependent on the environmental conditions. Factors such as temperature, $\mathrm{pH}$, UV radiation, light and nutrient availability can adversely affect the growth, physiology, photosynthetic rate, metabolic rate and biochemical composition of the microalgae. In order to protect and adapt against environmental perturbations and abiotic stresses, microalgae employ a series of responses by altering levels of primary metabolites, secondary metabolites, photosynthetic intermediates, ion fluxes and osmolytes (Arbona et al., 2013).

Human activities emitted greenhouse gases since the Industrial Revolution. As a result, heat from the sun is trapped in the form of 
infrared rays, causing elevated temperatures across the globe (Gao et al., 2012). This inflicts a number of scenarios in the ocean. Rising temperature decreases the density of the ocean surface. As a result, stratification over the water column are enhanced, thereby reducing the depth of the upper mixing layer (UML). Reduction of UML depth brings more photosynthetic marine microalgae closer to the surface of the sea, a situation where more microalgae could be subjected to stresses of drastic light and ultraviolet (UV) fluctuations. In the open ocean, shallowing of UML results in marine microalgae receiving less nutrients from the deeper ocean (Steinacher et al., 2009).

Anthropogenic release of carbon dioxide $\left(\mathrm{CO}_{2}\right)$ increases the dissociation of dissolved $\mathrm{CO}_{2}$ to hydrogen and bicarbonate ions in the seawater (Dickson, 2010). In the absence of mitigation efforts, atmospheric $\mathrm{pCO}_{2}$ is expected to rise up to $1000 \mu \mathrm{atm}$ in 100 years, leading to a further drop in oceanic $\mathrm{pH}$ of $0.20-0.32$ in the same period of time (Pachauri et al., 2014), a rate that is unprecedented over Earth's geological timescale (Zeebe et al., 2016). Other than the increase of acidity in the ocean, excessive hydrogen ions causes decrease of carbonate ions and saturation rate of calcium carbonate (Doney et al., 2009), which could threaten the calcifying microalgae (Meyer \& Riebesell, 2015).

Only $2.5 \%$ of the freely available water on the Earth's surface are from freshwater ecosystems, of which $68.7 \%$ is in frozen form, $29.9 \%$ is groundwater and only $0.26 \%$ of liquid freshwater ecosystems is in the form of rivers, lakes and reservoirs. Naturally the turnover time and flux of surface freshwaters is more rapid compared to the ocean, but the flux in freshwater is even more accelerated now due to climate change, and various industrial and anthropogenic activities (Carpenter et al.,
2011). Some of the impacts of climate change on freshwater ecosystems include rising temperature, irradiance, water body stratification and salinity (Wilby et al., 2010). These changes are also predicted to increase precipitation and nutrient upcycling of the freshwaters, hence affecting habitat availability, growth and species distribution of aquatic organisms, especially primary producers such as microalgae (Prowse et al., 2006).

This review includes some of the recent research on the impacts of changing environmental drivers (irradiance, temperature, $\mathrm{CO}_{2}$, salinity) to microalgae and some of the interactive effects of these drivers will be discussed.

\section{Irradiance}

As discussed above, microalgae in the euphotic zone are subjected to high fluctuations of light. Stratification of the ocean surface due to climate change further exacerbates the light stress on microalgae. Perturbations in light intensity can be detrimental to photosynthesis and consequently affects the productivity of the microalgal community, as summarized in Table 1. Recent reports found that microalgae could alter their chlorophyll content, phycobiliprotein content, photosystem ratio, photosystem antenna size, biomolecule ratio and nutrient uptake as the light intensity increased (Norici et al., 2011; Ma et al., 2015; Meneghesso et al., 2016). To mitigate the excessive energy of high light, microalgae undergo nonphotochemical quenching (NPQ) via cyclic electron flow in PSI, Mehler reaction, carbon concentrating mechanisms (CCM), photorespiration, carbon excretion (Lepetit et al., 2012), and de-epoxidation of xanthophyll pigments (violaxanthin, zeaxanthin and diadinoxanthin) (Goss \& Jakob, 2010; Katayama \& Taguchi, 2013; Meneghesso et al., 2016). 
Table 1: Summary of various reports on light intensity and ultraviolet radiation on microalgae.

\begin{tabular}{|c|c|c|c|}
\hline Species & Manipulated factors & Effects & Reference \\
\hline $\begin{array}{l}\text { Nostoc } \\
\text { sphaeroides } \\
\text { Kützing } \\
\text { Skeletonema } \\
\text { marinoi } \\
\text { Sarno \& } \\
\text { Zingone }\end{array}$ & $\begin{array}{l}\text { PAR: } 10,30,60,90 \\
\text { and } 120 \mu \mathrm{mol} \\
\text { photon } \mathrm{m}^{-2} \mathrm{~s}^{-1} \\
\text { PAR: } 25 \text { (low light, } \\
\text { LL), } 250 \text { (high } \\
\text { light, HL) } \mu \mathrm{mol} \\
\text { photon } \mathrm{m}^{-2} \mathrm{~s}^{-1}\end{array}$ & $\begin{array}{l}\text { Phycocyanin and allophycocyanin: } \uparrow \text { with light } \\
\text { intensity } \\
\text { Phycoerythrin: } \downarrow \text { with light intensity } \\
\text { Specific growth rate, cell volume, ashes, P } \\
\text { (phosphorus) cell quota, } \mathrm{N} \text { (nitrogen) cell quota, } \\
\text { total protein, chlorophyll (Chl) a, Chl } \mathrm{c}_{1}+\mathrm{c}_{2} \text {, } \\
\text { total Chl, dark respiration rate, and PEPck } \\
\text { activity: } \downarrow \text { significantly in HL } \\
\text { Estimated net primary production, light } \\
\text { compensation point, } \mathrm{E}_{\mathrm{k}}: \uparrow \text { significantly in HL } \\
\text { Contribution to carbon pools (\% protein: lipids: } \\
\text { carbohydrates): LL cells }(66.6 \%: 5.4 \%: 10.1 \%) \text {; } \\
\text { HL cells (40.8\%: } 37.6 \%: 4.6 \% \text { ) }\end{array}$ & $\begin{array}{l}\text { Norici et al. } \\
\text { (2011) }\end{array}$ \\
\hline $\begin{array}{l}\text { Ice algal } \\
\text { community }\end{array}$ & $\begin{array}{l}\text { PAR: } 520 \rightarrow 1145 \\
\mu \mathrm{mol} \text { photon } \mathrm{m}^{-2} \mathrm{~s}^{-1}\end{array}$ & $\begin{array}{l}\text { DES (de-epoxidation state) and NPQ: } \uparrow \text { in high } \\
\text { light }\end{array}$ & $\begin{array}{l}\text { Katayama \& } \\
\text { Taguchi } \\
\text { (2013) }\end{array}$ \\
\hline $\begin{array}{l}\text { Pseudo- } \\
\text { nitzschia } \\
\text { multistriata } \\
\text { (Takano) } \\
\text { Takano }\end{array}$ & $\begin{array}{l}\text { PAR kinetics: } \\
-5 \mathrm{~h} \text { spike to } 100- \\
650 \mu \text { mol photon } \mathrm{m}^{-} \\
2 \mathrm{~s}^{-1} \text { (diel-cycle } \\
\text { related) } \\
-3 \mathrm{~h} \text { spike } / 2 \mathrm{~h} \text { spike } \\
\text { to } 100-650 \mu \mathrm{mol} \\
\text { photon } \mathrm{m}^{-2} \mathrm{~s}^{-1} \\
\text { (mixing }- \text { related) }\end{array}$ & $\begin{array}{l}\mathrm{Vx}_{\mathrm{X}} \mathrm{Chl} \mathrm{a}^{-1} \text { (violaxanthin per chlorophyll), Zx Chl } \\
\mathrm{a}^{-1} \text { (zeaxanthin per chlorophyll), Dt } \mathrm{Chl} \mathrm{a}^{-} \\
{ }^{1} \text { (diatoxanthin per chlorophyll), } \beta \text {-carotene } \mathrm{Chl} \mathrm{a} \mathrm{a}^{-} \\
{ }_{1} \text { (beta-carotene per chlorophyll), NPQ: } \\
\uparrow \text { increasing light intensity in diel cycle-related. } \\
\text { In mixing related light velocity is too fast to } \\
\text { initiate high operation compared to the diel-cycle } \\
\text { related, except NPQ } \uparrow \text { with Dt Chl } \mathrm{a}^{-1}\end{array}$ & $\begin{array}{l}\text { Giovagnetti } \\
\text { et al. (2014) }\end{array}$ \\
\hline $\begin{array}{l}\text { Emiliania } \\
\text { huxleyi } \\
\text { (Lohmann) } \\
\text { W.W.Hay \& } \\
\text { H.P.Mohler }\end{array}$ & $\begin{array}{l}50 \mu \text { mol photon } \mathrm{m}^{-2} \\
\mathrm{~s}^{-1} \text { (low light, LL), } \\
198 \mu \mathrm{mol}_{\text {photon }} \mathrm{m}^{-} \\
2 \mathrm{~s}^{-1}, 2.1 \mathrm{Wm}^{-2} \\
\left(\mathrm{UVA}^{-2}, 0.0885\right. \\
\mathrm{Wm}^{-2} \text { (UVB) (high } \\
\text { light, HL) } \\
\text { Rapid from } \\
\mathrm{LL} \rightarrow \mathrm{HL}\end{array}$ & DMSP concentration: $\uparrow \mathrm{LL} \rightarrow \mathrm{HL}$ & $\begin{array}{l}\text { Darroch et } \\
\text { al. }(2015)\end{array}$ \\
\hline
\end{tabular}


Table 1: Summary of various reports on light intensity and ultraviolet radiation on microalgae. (con't)

\begin{tabular}{|c|c|c|c|}
\hline $\begin{array}{l}\text { Emiliania huxleyi } \\
\text { (Lohmann) } \\
\text { W.W.Hay \& } \\
\text { H.P.Mohler }\end{array}$ & $\begin{array}{l}\text { 4-day acclimation } \\
\text { in } 18 \mu \text { mol photon } \\
\mathrm{m}^{-2} \mathrm{~s}^{-1}(\mathrm{LL}) \text { in } \\
\text { green/blue spectral } \\
\text { light, and white HL } \\
(425 \mu \text { mol photon } \\
\left.\mathrm{m}^{-2} \mathrm{~s}^{-1}\right) \\
\text { Upwelling } \\
\text { simulation } \\
\text { - green LL } \rightarrow \\
\text { white HL (coastal) } \\
\text { - blue LL } \rightarrow \text { white } \\
\text { HL (oceanic) } \\
\text { Downwelling } \\
\text { simulation white } \\
\text { HL } \rightarrow \text { green } \\
\text { LL(coastal) white } \\
\text { HL } \rightarrow \text { green } \\
\text { LL(oceanic) }\end{array}$ & $\begin{array}{l}\text { Chl } c_{2}, \mathrm{Chl}_{3}, \mathrm{~F} \text { : chl a ratio: } \uparrow \text { in downwelling. } \\
\mathrm{MV} \text { chl } \mathrm{c}_{3} \text { : chl a, diadinoxanthin }+ \text { diatoxanthin } \\
(\mathrm{Dt}+\mathrm{Dd}) \text { : chl a, XC pigments: } \uparrow \text { during } \\
\text { upwelling } \\
\text { F(fucoxanthin): chl a ratio: } \downarrow \text { downwelling } \\
\text { HF(19'-hexanoyloxyfucoxanthin): dominant in } \\
\text { coastal upwelling. } \\
\text { HF: chl a ratio: } \uparrow \text { in oceanic upwelling } \\
\mathrm{F} \text { and HF inversely and significantly correlated } \\
\text { in downwelling and upwelling. } \\
\text { DES (de-epoxidation state): } \uparrow \text { during upwelling, } \\
\downarrow \text { rapidly during downwelling } \\
\mathrm{F}_{\mathrm{v}} / \mathrm{F}_{\mathrm{m}} \text { (effective quantum yield): } 0.6 \rightarrow 0.4 \\
\text { (upwelling), } 0.4 \rightarrow 0.6 \text { (downwelling) }\end{array}$ & $\begin{array}{l}\text { Garrido et } \\
\text { al. (2016) }\end{array}$ \\
\hline $\begin{array}{l}\text { Nannochloropsis } \\
\text { gaditana } \\
\text { L.M.Lubián }\end{array}$ & $\begin{array}{l}\text { PAR: } 10 \text { (LL), } 100 \\
\text { (ML) and } 1000 \\
(\mathrm{HL}) \mu \mathrm{mol} \text { photon } \\
\mathrm{m}^{-2} \mathrm{~s}^{-1}\end{array}$ & $\begin{array}{l}\mathrm{Chl} \text { a, } \mathrm{F}_{v} / \mathrm{F}_{\mathrm{m}} \text {, PS I content per cell, PSII/PSI } \\
\text { ratio, PSII and PSI antenna size: significantly } \downarrow \\
\mathrm{LL} \rightarrow \mathrm{HL} \\
\text { Alterations of thylakoid membrane and highly } \\
\text { damaged cells in HL } \\
\text { Carotenoids: } \uparrow \text { in violaxanthin in HL } \\
\text { XC pools: } \uparrow \mathrm{XC} \text { pigments (antheraxanthin, } \\
\text { zeaxanthin) LL } \rightarrow \text { ML, remains in HL } \\
\text { NPQ: HL cells activate NPQ }>700 \mu \text { mol } \\
\text { photon } \mathrm{m}^{-2} \mathrm{~s}^{-1} \\
\text { Cyclic electron flow: } \uparrow \mathrm{ML} \rightarrow \mathrm{HL}\end{array}$ & $\begin{array}{l}\text { Meneghesso } \\
\text { et al. (2016) }\end{array}$ \\
\hline $\begin{array}{l}\text { Skeletonema } \\
\text { costatum } \\
\text { (Greville) Cleve }\end{array}$ & UVB: $17.3 \mathrm{~kJ} \mathrm{~m}^{-2}$ & 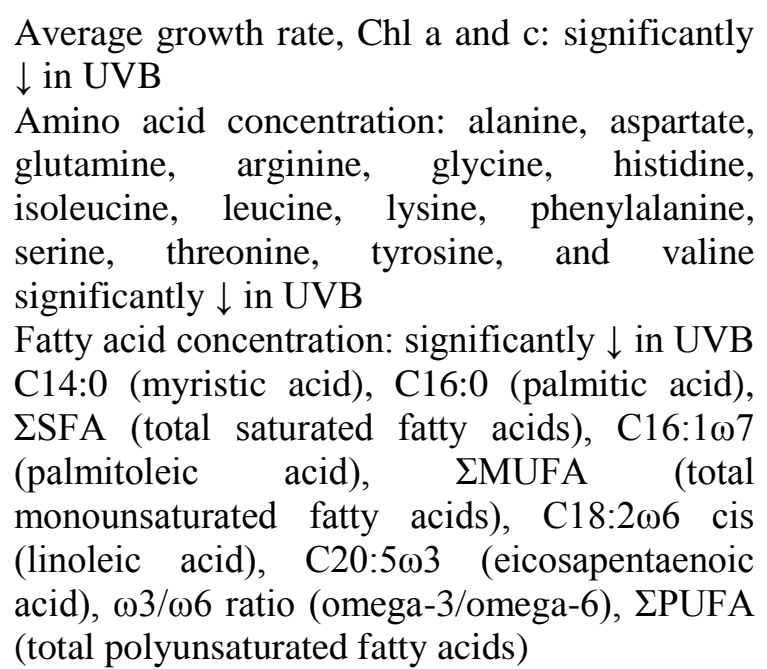 & $\begin{array}{l}\text { Nahon et al. } \\
\text { (2010) }\end{array}$ \\
\hline
\end{tabular}


Table 1: Summary of various reports on light intensity and ultraviolet radiation on microalgae. (con't)

\begin{tabular}{|c|c|c|c|}
\hline $\begin{array}{l}\text { Chlorella vulgaris } \\
\text { Beijerinck }\end{array}$ & $\begin{array}{l}\text { PAR+UVA }(8.54 \\
\left.\mathrm{Wm}^{-2}\right)+\mathrm{UVB}(1.17 \\
\left.\mathrm{Wm}^{-2}\right), \text { PAR+UVA } \\
\text { and PAR. }\end{array}$ & $\begin{array}{l}\text { Growth: significantly } \downarrow \text { PAR+UVA+UVB } \\
\text { FA: MUFA and PUFA significantly } \uparrow \text { in } \\
\text { PAR+UVA/PAR+UVA+UVB }\end{array}$ & $\begin{array}{l}\text { Wong et al. } \\
(2011)\end{array}$ \\
\hline $\begin{array}{l}\text { Chlorella vulgaris } \\
\text { Beijerinck }\end{array}$ & $\begin{array}{l}\text { UVB: } 3 \\
\text { consecutive days, } \\
60 \text { minutes, } 16920 \\
\mathrm{Jm}^{-2} \text { each day. }\end{array}$ & $\begin{array}{l}\text { Production of total phenols: } \uparrow \text { significantly in } \\
\text { UVB }\end{array}$ & $\begin{array}{l}\text { Copia et al. } \\
(2012)\end{array}$ \\
\hline $\begin{array}{l}\text { Phaeocystis spp. } \\
\text { Cryptomonas spp. } \\
\text { Bacillariophyceae } \\
\text { Dinophyceae }\end{array}$ & $\begin{array}{l}12.1 \mathrm{Wm}^{-2}, 72 \mathrm{hrs} \\
\text { incubation }\end{array}$ & $\begin{array}{l}\% \text { of FA production: SFA and MUFA } \uparrow \text {; PUFA } \\
\downarrow \text { in UVB }\end{array}$ & $\begin{array}{l}\text { Ha et al. } \\
\text { (2014) }\end{array}$ \\
\hline $\begin{array}{l}\text { Thalassiosira } \\
\text { weissflogii } \\
\text { (Grunow) } \\
\text { G.Fryxell \& Hasle } \\
\text { Dunaliella } \\
\text { tertiolecta } \\
\text { Butcher } \\
\text { Thalassiosira } \\
\text { pseudonana } \\
\text { Hasle \& Heimdal }\end{array}$ & $\begin{array}{l}\text { UV depleted (PAR } \\
\text { only), ambient UV } \\
\text { and PAR and } \\
\text { enhanced UV and } \\
\text { PAR (UV+) }\end{array}$ & 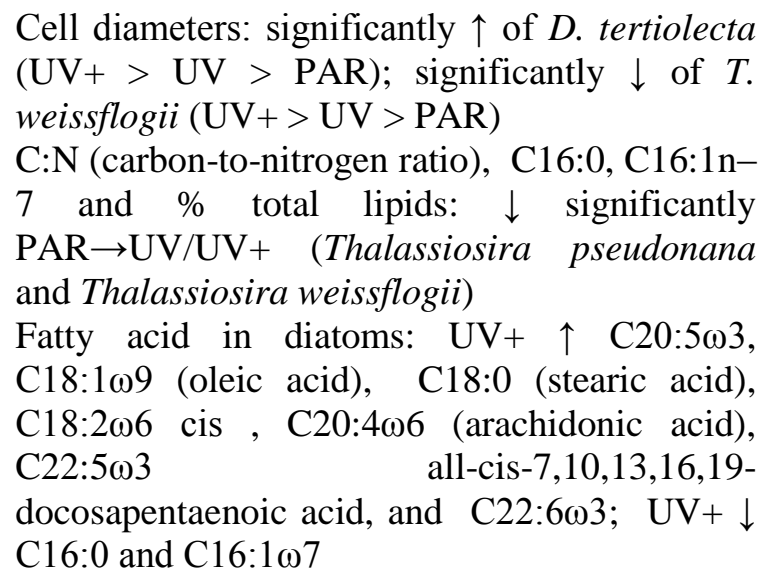 & $\begin{array}{l}\text { Durif et al. } \\
(2015)\end{array}$ \\
\hline
\end{tabular}


Apart from high incidents of light on the water surface, microalgae also experience drastic variations of light intensity due to vertical mixing or diel cycles (Ryther \& Menzel, 1959). Fucoxanthin pigments, chlorophyll content, xanthophyll pools and effective quantum yield $\left(\mathrm{F}_{\mathrm{v}} / \mathrm{F}_{\mathrm{m}}\right)$ were actively regulated by marine microalgae to adapt to changes in light intensity during downwelling and upwelling conditions and variations in diel cycle/mixing-cycle (Giovagnetti et al., 2014; Garrido et al., 2016). Yang et al. (2015) reported that species distribution in a freshwater community varied across the water column with decreasing light intensity.

Ultraviolet radiations [UV-A $(320-400 \mathrm{~nm})$; UV-B (280-320nm); UVC (200- $280 \mathrm{~nm})$ (Wong \& Parisi, 1999)] may inflict damage on intracellular biomolecules such as nucleic acids, membranes, pigments and proteins such as ribulose-1,5-bisphosphate carboxylase/oxygenase (RuBisCO) and photosystem (PS) II (Hughes, 2006). Damage to these biomolecules releases reactive oxygen species (ROS) which are scavenged by detoxifying enzymes such as superoxide dismutase (SOD) and ascorbate peroxidase (APX) (Janknegt et al., 2009), and organic sulphur such as dimethylsulfoniopropionate (DMSP) and dimethylsulfide (DMS) (Darroch et al., 2015). In response to UVR, fatty acid contents were found to be altered in a species-specific manner (Nahon et al., 2010; Wong et al., 2011; Ha et al., 2014; Durif et al., 2015).

\section{Temperature}

Temperature is a key environmental factor that strongly regulates the growth of photosynthetic organisms. Higher temperature in the environment impairs photosynthetic rate, affects viability of PSII and fluidity of the thylakoid membrane, lowers biomass production (Zidarova \& Pouneva, 2006) and alters biochemical profiles of microalgae (Teoh et al., 2005). Generally, growth and biochemical profiles of microalgae were different at optimal, suboptimal and stressful growth temperatures. Microalgae of the same taxonomic group but originating from different latitudes or climactic regions may respond differently to temperature stress in terms of their specific growth rate, lipid and fatty acid profiles. For example, Antarctic and temperate Chlamydomonas strains showed an increase in saturated fatty acids (SFA) with increasing temperature whereas for tropical strain, unsaturated fatty acids (UFA) increased and SFA decreased (Teoh et al., 2013). Lipid composition and membrane fluidity of microalgae cells were reported to be temperature-dependent (Lukeš et al., 2014). A trend of desaturation was observed in the fatty acid profile of Antarctic Chlamydomonas sp. ICE-L at $15^{\circ} \mathrm{C}$ in which the expression level of mRNAs for fatty acid desaturases changed following elevation of temperature (An et al., 2013). Thermal fluctuations also affect fluidity and functioning of PSII on the thylakoid membrane, which subsequently influence photosynthetic rate and aggravate photoinhibition (Smirnoff, 1995).

Some microalgae species are able to thrive in various environments such as extreme cold and harsh heat of hot springs in spite of a reduced growth rate and changes in physiological and biochemical profiles. Based on their optimal growth temperature, species can be briefly categorised as (1) psychrophiles growing at $<15^{\circ} \mathrm{C}$, (2) thermophiles growing at $>500^{\circ} \mathrm{C}$, (3) mesophiles growing at intermediate temperatures, and (4) hyperthermophiles which thrive at $>80^{\circ} \mathrm{C}$ (Varshney et al., 2015). Chlorella sp. isolated from the Arctic glacier melt water was reported to be a psychrotolerant due to its adaptability to 
grow from $3-27^{\circ} \mathrm{C}$. Photosynthetic parameters showed that the strain was more tolerant to heat than cold stress (Cao et al., 2016). Adaptations of polar microalgae to extreme cold conditions include utilizing mechanisms such as membrane fluidity, enzyme kinetics, compatible solutes and cryoprotectants, extracellular compounds, light acclimation, antioxidants and dark adaptation (Lyon \& Mock, 2014). The eurythermal adaptability was crucial for the species to survive significant diurnal and seasonal temperature fluctuations in extreme environment (Cao et al., 2016).

Similar mechanisms were adopted by microalgae to acclimatize to heat stress. Acclimation of snow alga Chlamydomonas cf. nivalis to a wide range of temperatures might be due to the structural flexibility in the D1 protein of thylakoid membrane which consists largely of negatively charged phosphatidylglycerol (Lukeš et al., 2014). Interspecies variability for sensitivity to heat was also observed in Chlorella species where the Antarctic strain showed higher expression of HSP70B heat shock proteins (Chankova et al., 2013). The overall effects in heat stress can lead to reduced biomass production, reaction rates and kinetic properties of enzymes (Zidarova \& Pouneva, 2006). A hypothetical model proposed that the heat shock response in Chlamydomonas is a highly complex network which includes protein homeostasis of enzymes, molecular chaperones and transcripts, photosynthesis, ROS scavengers, membrane lipid remodelling and cell cycle (Schroda et al., 2015). Table 2 summarizes how microalgae respond to temperature stress.

Table 2: Summary of various reports on temperature stress on microalgae.

\begin{tabular}{|c|c|c|c|c|}
\hline Species & Origin & $\begin{array}{l}\text { Manipulated } \\
\text { factors }\end{array}$ & Effects & Reference \\
\hline $\begin{array}{l}\text { Chlamydomonas } \\
\text { cf. } \quad \text { nivalis } \\
\text { (F.A.Bauer) Wille }\end{array}$ & $\begin{array}{l}\text { Temperate } \\
\text { (strain } \\
\text { isolated } \\
\text { from } \\
\text { melting } \\
\text { snow) }\end{array}$ & $2.5-30^{\circ} \mathrm{C}$ & $\begin{array}{l}\text { Oxygen evolution rate } \downarrow \text {, } \\
\text { electron transfer rate } \downarrow \text {, change } \\
\text { in lipid composition }\end{array}$ & $\begin{array}{l}\text { Lukeš et al. } \\
(2014)\end{array}$ \\
\hline Chlorella sp. & $\begin{array}{l}\text { Polar } \\
\text { (Arctic) }\end{array}$ & $3-27^{\circ} \mathrm{C}$ & $\begin{array}{l}\mathrm{F}_{\mathrm{v}} / \mathrm{F}_{\mathrm{m}} \text { increased with increasing } \\
\text { temperature with highest value } \\
\text { at } 21 \text { and } 27^{\circ} \mathrm{C} \text {. Extracellular } \\
\text { soluble sugar } \uparrow \text {. Protein } \downarrow \text {. } \\
\text { Total lipid } \downarrow \text {. }\end{array}$ & $\begin{array}{l}\text { Cao et al. } \\
(2015)\end{array}$ \\
\hline $\begin{array}{l}\text { Chlamydomonas } \\
\text { sp. ICE-L }\end{array}$ & $\begin{array}{l}\text { Polar } \\
\text { (Antarctic) }\end{array}$ & $-20-15^{\circ} \mathrm{C}$ & $\begin{array}{l}\text { mRNA expression levels of } \\
\text { fatty acid desaturases changed. } \\
\text { SFA } \uparrow, \text { PUFA } \downarrow \text { at } 15^{\circ} \mathrm{C} \text {. }\end{array}$ & An et al. (2013) \\
\hline
\end{tabular}




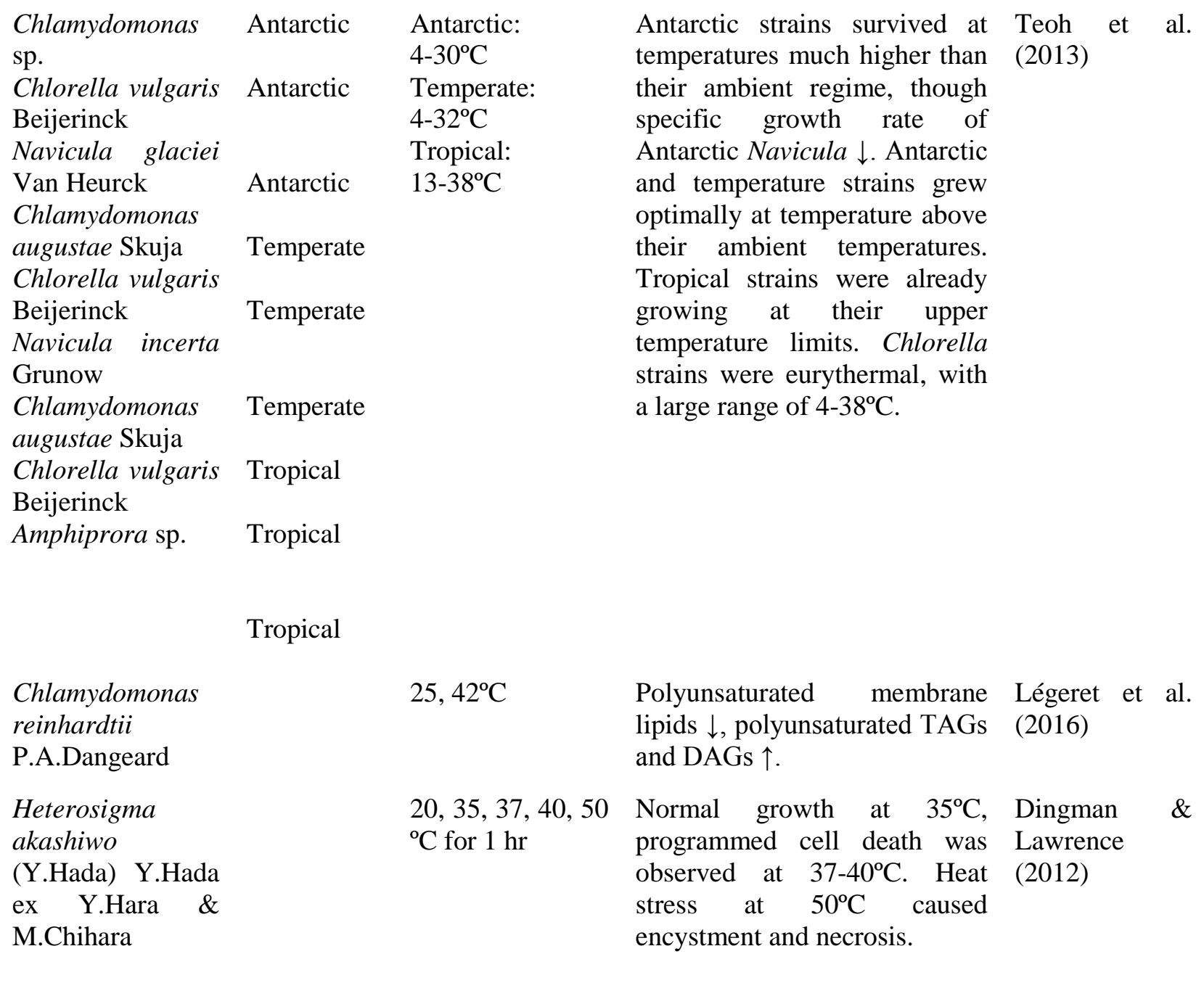

Table 2: Summary of various reports on temperature stress on microalgae. (con't)

\begin{tabular}{llll}
\hline $\begin{array}{l}\text { Alexandrium } \\
\text { tamarense }\end{array}$ & Temperate & $0-37^{\circ} \mathrm{C}$ & Survival rate $\downarrow$ at high Kobiyama et al. \\
(Lebour) Balech & Tropical & & temperature. Temperate strain $(2010)$ \\
& & was able to survive at $15-30^{\circ} \mathrm{C}$ \\
& for $1 \mathrm{~h}$. Tropical strain could \\
& tolerate a range of $15-30^{\circ} \mathrm{C}$. \\
& Induction of Hsp70 occurred \\
& more quickly in the temperate \\
& strain compared to the tropical \\
& one, hence better survival of \\
& the temperate strain.
\end{tabular}


$\begin{array}{ll}\begin{array}{l}\text { Symbiodinium } \\ \text { spp. }\end{array} & \begin{array}{l}\text { Temperate } \\ \text { Tropical }\end{array}\end{array} \quad 25,29,30,31^{\circ} \mathrm{C}$
ROS production, antioxidant McGinty et al. catalase and superoxide (2012) dismustase activity varied among the seven Symbiodinium types at elevated temperatures.

\section{Carbon Dioxide}

To undergo oxygenic photosynthesis in low atmospheric $\mathrm{CO}_{2}$ levels, marine microalgae had evolved carbon concentrating mechanisms (CCM) to accumulate $\mathrm{CO}_{2}$ in a RuBisCO-containing intracellular compartment since 60 million years ago (Raven et al, 2012). With increasing levels of oceanic $\mathrm{CO}_{2}$ level, $\mathrm{CCM}$ are expected to be downregulated as more carbon is readily available. This might result in energy saving, despite more carbon fixation and higher respiration rate ( $\mathrm{Wu}$ et al., 2010). To date, studies have shown that the increase of $\mathrm{CO}_{2}$ levels benefit marine microalgae by improving growth rates, photosynthetic carbon fixation, nitrogen fixation and photoprotection (NPQ) (Levitan et al., 2007; $\mathrm{Wu}$ et al., 2010; Sun et al., 2011; Torstensson et al., 2012; Eichner et al., 2014).

For the calcifying microalgae species, such as the model haptophytes Emiliania huxleyi, Calcidiscus leptoporus, and Gephyrocarpsa oceanica, increasing seawater acidity reduces calcification (length and weight of the coccoliths, particulate inorganic carbon (PIC) production). While haptophytes were found to be flexibly regulating carbon assimilation in different $\mathrm{pH}$ levels (Kottmeier et al., 2014), the organic carbon fixation rate varied among species (Barcelos et al., 2010; Langer \& Bode, 2011; Zhang et al., 2015). This could be due to the increase of protons accumulated during ocean acidification (Suffrian et al., 2011) or slower rates of photosynthetic electron transfer compare to carbon fixation (Barcelos $\mathrm{E}$ Ramos et al., 2010).

Reports on the response of individual species might vary in in situ ecological studies. Result of a community study suggested that when marine microalgae were cultured in a mesocosm, high $\mathrm{CO}_{2}$ elevated the abundance of picoeukaryotes (Newbold et al., 2012). On the other hand, a 12-years in situ study on the mean weight of $E$. huxleyi coccolith suggested that rising global atmospheric $\mathrm{CO}_{2}$ contributed to the decrease of coccolithophore calcification (Meier et al., 2014).

Elevated $\mathrm{CO}_{2}$ level was also reported to alter the fatty acid composition and increase phenolic acid content of marine microalgae. This would directly affect its quality as food source across the trophic levels (Rossoll et al., 2012; Jin et al., 2015). More worrying is the fact that harmful algae are expected to release more neurotoxin under conditions of increased $\mathrm{CO}_{2}$ levels (Sun et al., 2011). Engel (2002) hypothesized that the high $\mathrm{CO}_{2}$ could result in high exudation of transparent exopolymer particles (TEP) into the ocean. As marine microalgae interact closely in the phycosphere, the release of biomolecules allows us to infer the chemical interaction between each species of an algal community in a high- $\mathrm{CO}_{2}$ aquatic environment. Table 3 is a summary of the responses of microalgae to elevating $\mathrm{CO}_{2}$ 
Table 3: Summary of various reports on $\mathrm{pCO}_{2}$ manipulation on microalgae.

\begin{tabular}{|c|c|c|c|}
\hline Species & Manipulated factors & Effects & Reference \\
\hline $\begin{array}{l}\text { Trichodesmium } \\
\text { sp. (IMS101) }\end{array}$ & $\begin{array}{l}\mathrm{pCO}_{2}: 250 \text { (low), } 400 \\
\text { (ambient), } 900 \mu \mathrm{atm} \\
\text { (high) }\end{array}$ & $\begin{array}{l}\text { Growth rate, biomass, nitrogen fixation, } \mathrm{C}: \mathrm{N} \\
\text { ratio, filament length: significantly } \uparrow \text { high } \\
\mathrm{CO}_{2} \\
\mathrm{E}_{\mathrm{k}} \text { : significantly } \downarrow \text { in high } \mathrm{CO}_{2}\end{array}$ & $\begin{array}{l}\text { Levitan et } \\
\text { al. (2007) }\end{array}$ \\
\hline $\begin{array}{l}\text { Emiliania } \\
\text { huxleyi } \\
\text { (Lohmann) } \\
\text { W.W.Hay \& } \\
\text { H.P.Mohler }\end{array}$ & $\begin{array}{l}\mathrm{pCO}_{2}: 190,410,800, \\
1500 \mu \mathrm{atm}\end{array}$ & $\begin{array}{l}\text { Organic carbon fixation } \uparrow \text { high } \mathrm{CO}_{2} \\
\text { Calcification, ratio of calcification to organic } \\
\text { carbon } \\
\text { fixation, cell division rate: } \downarrow \text { in high } \mathrm{CO}_{2}\end{array}$ & $\begin{array}{l}\text { Barcelos E } \\
\text { Ramos et } \\
\text { al. (2010) }\end{array}$ \\
\hline $\begin{array}{l}\text { Phaeodactylum } \\
\text { tricornutum } \\
\text { Bohlin }\end{array}$ & $\begin{array}{l}\mathrm{pCO}_{2}: 388 \mu \mathrm{atm} \\
\text { (ambient) and } \\
1000 \mu \text { atm (high) } \\
\mathrm{LC}: \text { low- } \mathrm{CO}_{2} \text { grown } \\
\text { cells } \\
\mathrm{HC} \text { : high- } \mathrm{CO}_{2} \text { grown } \\
\text { cells }\end{array}$ & $\begin{array}{l}\text { Specific growth rate: } \uparrow \text { in } \mathrm{HC} \text { than } \mathrm{LC} \text {. } \\
\text { Photosynthetic carbon fixation rate: } \\
\text { significant } \uparrow 11 \% \text { at } \mathrm{HC} \\
\mathrm{K}_{\mathrm{m}} \text {, dark respiration, daily net production, } \\
\text { photochemical activity, and: } \uparrow \text { in HC } \\
\text { rETR(relative electron transport rate)and } \\
\left.\text { maximum rETR (rETR }{ }_{\max }\right) \text { NPQ: } \\
\text { significantly } \downarrow \mathrm{HC}\end{array}$ & $\begin{array}{l}\text { Wu et al. } \\
\text { (2010) }\end{array}$ \\
\hline $\begin{array}{l}\text { Calcidiscus } \\
\text { leptoporus } \\
\text { (G.Murray \& } \\
\text { V.H.Blackman) } \\
\text { Loeblich Jr. \& } \\
\text { Tappan }\end{array}$ & $\begin{array}{l}\mathrm{pCO}_{2}: 260 \text { to } 1600 \\
\mu \mathrm{atm}\end{array}$ & $\begin{array}{l}\text { Growth rate: } \downarrow \text { in higher } \mathrm{CO}_{2} \\
\% \text { malformed coccoliths and cellular POC } \\
\text { content: } \uparrow \text { in higher } \mathrm{CO}_{2}\end{array}$ & $\begin{array}{l}\text { Langer \& } \\
\text { Bode } \\
(2011)\end{array}$ \\
\hline $\begin{array}{l}\text { Pseudo- } \\
\text { nitzschia } \\
\text { multiseries } \\
\text { (Hasle) Hasle }\end{array}$ & $\begin{array}{l}\mathrm{pCO}_{2}: 220,400 \text {, and } \\
730 \mu \mathrm{atm}\end{array}$ & $\begin{array}{l}\text { Specific growth rate, carbon fixation rate, } \mathrm{DA} \\
\text { (domoic acid), C:P (carbon-to-phosphorus) } \\
\text { ratio: } \uparrow \text { in high } \mathrm{CO}_{2} \\
\mathrm{Q}_{\mathrm{Si}} \text { (cellular quotas of silicon) and } \mathrm{Si}: \mathrm{C} \text { ratio: } \\
\downarrow \text { in high } \mathrm{CO}_{2}\end{array}$ & $\begin{array}{l}\text { Sun et al. } \\
\text { (2011) }\end{array}$ \\
\hline
\end{tabular}

Table 3: Summary of various reports on $\mathrm{pCO}_{2}$ manipulation on microalgae. (con't) 


\begin{tabular}{|c|c|c|c|}
\hline $\begin{array}{l}\text { Eukaryotes } \\
\text { - Coccolithophores } \\
\text { - Picoeukaryotes } \\
\text { (Micromonas sp. and } \\
\text { Bathycoccus sp.) }\end{array}$ & $\begin{array}{l}\mathrm{pCO}_{2}: 750 \mu \mathrm{atm} \\
\text { (high } \mathrm{CO}_{2} \text { ) } \\
\text { Mesocosm: } 11000 \\
\text { litres, } 2 \text { days, } \\
\text { nitrate and } \\
\text { phosphate added } \\
\text { to simulate } \\
\text { blooming. }\end{array}$ & $\begin{array}{l}\text { Eukaryote cellular abundance: } \\
\text { Coccolithophores significantly } \downarrow \text { high } \\
\mathrm{CO}_{2} \\
\text { Picoeukaryote sequence abundance: } \uparrow \\
\text { Micromonas sp. and Bothycoccus in high } \\
\mathrm{CO}_{2}\end{array}$ & $\begin{array}{l}\text { Newbold et } \\
\text { al. (2012) }\end{array}$ \\
\hline $\begin{array}{l}\text { Thalassiosira pseudonana } \\
\text { Hasle \& Heimdal } \\
\text { Rhodomonas sp. }\end{array}$ & $\begin{array}{l}\mathrm{pCO}_{2} \text { : } \\
365 \text { (ambient) and } \\
915 \text { (high) } \mu \mathrm{atm} \\
(\text { T. pseudonana); } \\
495 \text { (ambient) and } \\
760 \text { (high) } \mu \mathrm{atm} \\
(495,760 \mu \mathrm{atm}) \\
\text { (Rhodomonas) }\end{array}$ & $\begin{array}{l}\text { FA: PUFA significantly } \downarrow \text {; SFA } \uparrow \text { at high } \\
\mathrm{CO}_{2} \text {; } \\
\text { Essential PUFA concentrations: } \downarrow \text { ( } T \text {. } \\
\text { pseudonana) specifically in DHA and } \\
\text { ARA-EPA }\end{array}$ & $\begin{array}{l}\text { Rossoll et } \\
\text { al. (2012) }\end{array}$ \\
\hline $\begin{array}{l}\text { Navicula directa } \\
\text { (W.Smith) Ralfs }\end{array}$ & $\begin{array}{l}\mathrm{pCO}_{2}: 380 \\
\text { (ambient) and } 960 \\
\mu \text { atm (high) }\end{array}$ & $\begin{array}{l}\text { Specific growth rate: significant } \uparrow \text { in high } \\
\mathrm{CO}_{2} \\
\text { Concentrations of } \mathrm{Chl} \text { a and DD } \\
\text { significant } \downarrow \text { in high } \mathrm{CO}_{2}\end{array}$ & $\begin{array}{l}\text { Torstensson } \\
\text { et al. (2012) }\end{array}$ \\
\hline $\begin{array}{l}\text { Thalassiosira pseudonana } \\
\text { Hasle \& Heimdal }\end{array}$ & $\begin{array}{l}\mathrm{pCO}_{2}: 390 \\
\text { (ambient) and } \\
1000 \mu \text { atm (high) } \\
\text { LC: } 1 \text { ow- } \mathrm{CO}_{2} \\
\text { grown cells } \\
\mathrm{HC}: \text { high- } \mathrm{CO}_{2} \\
\text { grown cells }\end{array}$ & $\begin{array}{l}\mathrm{P}_{\max }(\mathrm{rETR}) \quad \text { (maximum photosynthetic } \\
\text { rate) and } \mathrm{I}_{\mathrm{k}}: \text { Significantly } \downarrow \text { in } \mathrm{HC} \\
\text { Photosynthetic carbon fixation rate and } \\
\text { dark respiration rate: } \uparrow \mathrm{HC} \text {. }\end{array}$ & $\begin{array}{l}\text { Yang \& } \\
\text { Gao (2012) }\end{array}$ \\
\hline $\begin{array}{l}\text { Nitzschia lecointei van } \\
\text { Heurck }\end{array}$ & $\begin{array}{l}\mathrm{pCO}_{2}: 380 \\
\text { (ambient) and } 960 \\
\mu \text { atm (high) }\end{array}$ & $\begin{array}{l}\text { Growth rate and total FA content: } \\
\text { significant } \uparrow \text { in high } \mathrm{CO}_{2}\end{array}$ & $\begin{array}{l}\text { Torstensson } \\
\text { et al. (2013) }\end{array}$ \\
\hline $\begin{array}{l}\text { Prasinophytes, } \\
\text { dinoflagellates, } \\
\text { cyanobacteria and } \\
\text { chrysophytes, } \\
\text { chlorophytes/haptophytes, } \\
\text { and diatoms }\end{array}$ & $\begin{array}{l}\mathrm{pCO}_{2}: 185- \\
1420 \mu \mathrm{atm} \\
\text { Mesocosm: } 30 \\
\text { days, nutrient } \\
\text { addition on day } 13 \\
\text { to initiate } \\
\text { blooming }\end{array}$ & $\begin{array}{l}\text { Prasinophytes and dinoflagellates: } \\
\text { majority during the bloom during high } \\
\mathrm{CO}_{2} \\
\text { Diatoms: Biomass } \downarrow \text { in higher } \mathrm{CO}_{2} \text { levels } \\
\text { Cryptophytes, chlorophytes/haptophytes, } \\
\text { Chrysophytes: Biomass significantly } \\
\text { correlated to high } \mathrm{CO}_{2}\end{array}$ & $\begin{array}{l}\text { Schulz et al. } \\
\text { (2013) }\end{array}$ \\
\hline
\end{tabular}


Nodularia spumigena Mertens ex Bornet \& Flahault
$\mathrm{pCO}_{2}: 249-499$ $\mu$ atm (low), $287-571 \mu$ atm (medium), $395-630 \mu \mathrm{atm}$ (high)
Biomass production, total concentrations Endres et al. of mucinous substances and APA (2013) (alkaline phosphatase activity): significant $\uparrow$ in the medium and high $\mathrm{CO}_{2}$

\begin{tabular}{|c|c|c|c|}
\hline $\begin{array}{l}\text { Trichodesmium } \\
\text { erythraeum } \\
\text { Ehrenberg ex } \\
\text { Gomont } \\
\text { (IMS 101) }\end{array}$ & $\begin{array}{l}\mathrm{pCO}_{2}: 180,380,980 \\
\text { and } 1400 \mu \mathrm{atm}\end{array}$ & $\begin{array}{l}\mathrm{N}_{2} \text { fixation: approximately } \uparrow \text { from } 380- \\
1400 \mu \text { atm. } \\
\text { POC and PON: significantly } \uparrow \text { from } 180- \\
1400 \mu \text { atm } \\
\mathrm{N}_{2} \text { fixation with } \mathrm{C} \text { acquisitions correlated } \\
\text { diurnally }\end{array}$ & $\begin{array}{l}\text { Eichner et } \\
\text { al. (2014) }\end{array}$ \\
\hline $\begin{array}{l}\text { Emiliania } \\
\text { huxleyi } \\
\text { (Lohmann) } \\
\text { W.W.Hay \& } \\
\text { H.P.Mohler }\end{array}$ & In situ study & $\begin{array}{l}\text { Coccolith weight: } \downarrow \text { across } \uparrow \mathrm{CO}_{2} \text { from 1993- } \\
2005\end{array}$ & $\begin{array}{l}\text { Meier et al. } \\
(2014)\end{array}$ \\
\hline $\begin{array}{l}\text { Emiliania } \\
\text { huxleyi } \\
\text { (Lohmann) } \\
\text { W.W.Hay \& } \\
\text { H.P.Mohler } \\
\text { (RCC1216 - } \\
\text { calcifying, } \\
\text { diploid) RCC } \\
\text { 1217 (non- } \\
\text { calcifying, } \\
\text { haploid) }\end{array}$ & $\begin{array}{l}\mathrm{pCO}_{2}: 380 \text { (ambient), } \\
950 \text { (high) } \mu \mathrm{atm}\end{array}$ & $\begin{array}{l}\text { POC quotas, POC production rate (diploid } \\
\text { stage), PIC production: } \downarrow \text { in high } \mathrm{CO}_{2}\end{array}$ & $\begin{array}{l}\text { Kottmeier } \\
\text { et al. } \\
(2014)\end{array}$ \\
\hline $\begin{array}{l}\text { Gephyrocapsa } \\
\text { oceanica } \\
\text { Kamptner }\end{array}$ & $\begin{array}{l}\mathrm{pCO}_{2}: \approx 510,1050 \\
\text { and } 1520 \mu \mathrm{atm}\end{array}$ & $\begin{array}{l}\text { Growth rate, POC production rate, PIC } \\
\text { production rate, rETR } \mathrm{max}_{\max } \downarrow \downarrow \text { significantly in } \\
\text { high } \mathrm{CO}_{2}\end{array}$ & $\begin{array}{l}\text { Zhang et al. } \\
\text { (2015) }\end{array}$ \\
\hline $\begin{array}{l}\text { Cylindrotheca } \\
\text { fusiformis } \\
\text { Reimann \& } \\
\text { J.C.Lewin }\end{array}$ & $\begin{array}{l}\mathrm{pCO}_{2}: 180(\text { low }) \\
380(\text { ambient }), 750 \\
\text { (high) } \mu \text { atm }\end{array}$ & $\begin{array}{l}\text { PUFA and EAA (essential amino acids): } \uparrow \text { at } \\
\text { high } \mathrm{CO}_{2}\end{array}$ & $\begin{array}{l}\text { Bermúdez } \\
\text { et al. } \\
(2015)\end{array}$ \\
\hline $\begin{array}{l}\text { Emiliania } \\
\text { huxleyi } \\
\text { (Lohmann) } \\
\text { W.W.Hay \& } \\
\text { H.P.Mohler }\end{array}$ & $\begin{array}{l}\mathrm{pCO}_{2}: 395 \text { (ambient), } \\
1000 \text { (high) } \mu \text { atm }\end{array}$ & $\begin{array}{l}\text { Phenolic acid content, mitochondrial } \\
\text { respiration rate: } \uparrow \text { at high } \mathrm{CO}_{2}\end{array}$ & $\begin{array}{l}\text { Jin et al. } \\
(2015)\end{array}$ \\
\hline
\end{tabular}




\section{Salinity}

Salinity fluctuation in freshwater and marine environments is another abiotic factor that can have deleterious effects on aquatic organisms. Salt stress reduced cell viability and photosynthetic efficiency, induced cytoplasmic vacuolization and ROS production, and caused deformation of organelles in a freshwater alga, Micrasterias denticulate (Affenzeller et al., 2009). Salt treatment also decreased enzymatic antioxidant activity in Dunaliella salina and its tolerance to salt stress was proposed to be improved by using a synthetic antioxidant to induce $\beta$-carotene biosynthesis (Einali \& Valizadeh, 2015).
In general, different levels of salinity were reported to alter lipid content, fatty acid composition and biomass of microalgae (Pal et al., 2011; Salama et al., 2013). Changes of lipid profiles in response to salinity are in direct relation to cell membrane stability, photosynthetic rate and signal transduction (Lu et al., 2012). Under varying salt concentrations, mechanisms such as ion homeostasis and compartmentalization, ion transport and uptake, osmoprotectants and solutes, antioxidant regulation and enzyme activity were triggered to acclimatize to the osmotic stress (Gupta \& Huang, 2014). How microalgae respond during period of osmotic stresses are summarized in Table 4.

Table 4: Summary of various reports on salinity stress on microalgae.

\begin{tabular}{|c|c|c|c|c|}
\hline Species & Origin & $\begin{array}{l}\text { Manipulated } \\
\text { factors }\end{array}$ & Effects & Reference \\
\hline $\begin{array}{l}\text { Micrasterias } \\
\text { denticulata } \\
\text { Brébisson ex Ralfs }\end{array}$ & Freshwater & $\begin{array}{l}200 \mathrm{mM} \mathrm{NaCl} \text { or } \\
200 \mathrm{mM} \mathrm{KCl}\end{array}$ & $\begin{array}{l}\text { Cell viability } \downarrow \text {, change } \\
\text { in morphology, } F_{v} / F_{m} \downarrow \text {, } \\
\operatorname{ROS} \uparrow\end{array}$ & $\begin{array}{l}\text { Affenzeller et al. } \\
\text { (2009) }\end{array}$ \\
\hline $\begin{array}{l}\text { Tetraselmis suecica } \\
\text { (Kylin) Butcher } \\
\text { Nitzschia } \mathrm{sp} . \\
\text { Alexandrium } \\
\text { minutum Halim } \\
\text { Prorocentrum lima } \\
\text { (Ehrenberg) F.Stein }\end{array}$ & Marine & $5-35 \mathrm{psu}$ & $\begin{array}{l}\text { Photosynthesis and } \\
\text { growth were affected } \\
\text { under low salinity. } T \text {. } \\
\text { suecica showed the } \\
\text { highest tolerance. }\end{array}$ & $\begin{array}{l}\text { D'ors et al. } \\
(2016)\end{array}$ \\
\hline $\begin{array}{l}\text { Chlamydomonas } \\
\text { nivalis (F.A.Bauer) } \\
\text { Wille }\end{array}$ & Freshwater & $0-1.5 \% \mathrm{NaCl}$ & $\begin{array}{l}\text { Total, neutral and polar } \\
\text { lipids } \uparrow \text {. Polar lipid } \\
\text { molecules identified as } \\
\text { biomarkers } \\
\text { involved in cere } \\
\text { membrane stability, } \\
\text { signal transduction and } \\
\text { photosynthesis. }\end{array}$ & Lu et al. (2012) \\
\hline
\end{tabular}


Table 4: Summary of various reports on salinity stress on microalgae. (con't)

\begin{tabular}{|c|c|c|c|c|}
\hline $\begin{array}{l}\text { Desmodesmus } \\
\text { armatus (Chodat) } \\
\text { E.Hegewald } \\
\text { Mesotaenium sp. } \\
\text { Scenedesmus } \\
\text { quadricauda } \\
\text { Chodat } \\
\text { Tetraedron sp. }\end{array}$ & Freshwater & $\begin{array}{l}2,8,11,18 \mathrm{ppt} \\
(0.03,0.14,0.19 \\
\text { and } 0.31 \mathrm{M} \mathrm{NaCl})\end{array}$ & $\begin{array}{l}\text { Biomass productivity } \downarrow \\
\text { at } 18 \text { ppt. Minimal } \\
\text { effects on total lipid and } \\
\text { fatty acid contents. }\end{array}$ & $\begin{array}{l}\text { von Alvensleben } \\
\text { et al. (2016) }\end{array}$ \\
\hline Scenedesmus sp. & Freshwater & $0-400 \mathrm{mM} \mathrm{NaCl}$ & $\begin{array}{l}\text { Lipid and carbohydrate } \\
\uparrow . \quad \text { Stress biomarkers } \\
\text { such as hydrogen } \\
\text { peroxide, } \\
\text { malondialdehyde, } \\
\text { ascorbate peroxidase and } \\
\text { proline } \uparrow .\end{array}$ & $\begin{array}{l}\text { Pancha et al. } \\
\text { (2015) }\end{array}$ \\
\hline $\begin{array}{l}\text { Scenedesmus } \\
\text { quadricauda } \\
\text { Chodat }\end{array}$ & Freshwater & $0.2-1.0 \mathrm{mM} \mathrm{NaCl}$ & $\begin{array}{l}\text { Biomass yield } \downarrow \text {, total } \\
\text { Chl content } \downarrow \text {, } \\
\text { carbohydrate } \uparrow \text {. Initial } \\
\text { increase of } \mathrm{NaCl}(0- \\
0.2 \mathrm{mM}) \text {, lipid } \downarrow \text {. Total } \\
\text { protein } \downarrow \text { at } 0.2 \& \text { \& } 0.4 \\
\mathrm{mM} \text { and increased at } \\
\geq 0.6 \mathrm{mM} \text {. }\end{array}$ & $\begin{array}{l}\text { Kirrolia et al. } \\
(2011)\end{array}$ \\
\hline $\begin{array}{l}\text { Amphora } \\
\text { subtropica } \\
\text { A.H.Wachnicka \& } \\
\text { E.E.Gaiser } \\
\text { Dunaliella sp. }\end{array}$ & Marine & $\begin{array}{l}0.25,0.5,1,2,3.5, \\
5 \mathrm{M} \mathrm{NaCl}\end{array}$ & $\begin{array}{l}\text { With increasing salinity, } \\
\text { biomass productivity } \downarrow \text {, } \\
\text { total carotenoids content } \\
\uparrow, \text { Chl a and b } \downarrow \text {, } \\
\text { carbohydrate } \uparrow \text {, lipid } \uparrow \text {, } \\
\text { protein } \downarrow \text {. Degree of } \\
\text { unsaturation of the total } \\
\text { fatty acids decreased. } \\
\text { Thiobarbituric acid } \\
\text { reactive substances } \\
\text { (TBARS) and } \\
\text { superoxide dismutase } \\
\text { (SOD) activity } \uparrow\end{array}$ & $\begin{array}{l}\text { BenMoussa- } \\
\text { Dahmen et al. } \\
(2016)\end{array}$ \\
\hline $\begin{array}{l}\text { Botryococcus } \\
\text { braunii Kützing }\end{array}$ & Freshwater & $0.3,0.7 \mathrm{M} \mathrm{NaCl}$ & $\begin{array}{l}\text { With increasing salinity, } \\
\text { biomass yield } \downarrow \text {, lipid } \downarrow \text {, } \\
\text { SFA and MUFA } \uparrow \text {, } \\
\text { PUFA } \downarrow \text {. }\end{array}$ & $\begin{array}{l}\text { Zhila } \\
(2011)\end{array}$ \\
\hline
\end{tabular}




\section{Interactive effects of multiple environmental factors}

An increasing number of studies are reporting on the interactive effects of multiple stressors to provide a more comprehensive prediction on the effects of climate change on microalgae. Combinations of temperature, ultraviolet radiation, salinity stress and nutrient limitation are among the important conditions affecting the physiology and metabolism of microalgae.

Chlorella sp. isolated from the Antarctic region exhibited capacity for photosynthetic efficiency recovery after a combination of UV radiation and high temperature $\left(5-20^{\circ} \mathrm{C}\right)$ treatment (Rivas et al., 2016). In another study, Chlorella strains from Antarctic, temperate and tropical regions showed different photosynthetic patterns in response to integrative effects of PAR, UV-A, UV-B with a range of temperatures. The Antarctic Chlorella strain notably showed lower photosynthetic recovery compared to the temperate and tropical strains (Wong et al., 2015). Cell productivity of Scenedesmus acuminatus, Cyclotella meneghiniana, and Microcystis aruginosa increased under combined effects of elevated $\mathrm{CO}_{2}$ level and temperature. The increase in microalgal cellular carbohydrates and proteins may eventually lead to changes in carbon cycling in the ecosystem (Li et al., 2016). Beardall et al. (2014) reviewed on the interactive effects of temperature, nutrient supply, UVR and $\mathrm{CO}_{2}$ and suggested that UV-B is one of the important stressors which influence the impacts of other environmental factors on marine phytoplankton. However, the interdependency between the various factors and the mechanisms involved are still unclear. Effects of irradiance, temperature and photoperiod on the growth of microalgae were reported to be species-dependent (Singh \& Singh, 2014).

In general, stress response of photosynthetic organisms to drought, salinity, cold and heat stress involve a complex interaction of various mechanisms ranging from gene expression, protein expression, metabolic adjustment and morphological changes. Amino acids, polyamines, betaines, polyols, storage substances such as starch and fructans are commonly involved in the response to unfavourable growth conditions (Krasensky \& Jonak, 2012). By 2100, the future ocean conditions are predicted to be warmer, with higher iron content, higher $\mathrm{pCO}_{2}$ and nutrient-limited. Pseudonitzschia multiseries, a sub-Antarctic diatom used as a representative species was predicted to be able to acclimatize and adapt to the future conditions, subsequently altering regional productivity and biogeochemistry (Boyd et al., 2015).

Besides being the primary producer in the ecosystem, many microalgal strains are potential feedstock for biofuel. Multiple parameters were manipulated to optimize the growth conditions for high lipid and fatty acid productivity. In addition to providing insights into the lipid accumulation pathways, these studies were also useful to understand cellular responses to environmental changes. For example, a combination of high light intensity, high salinity and nitrogen-replete condition enhanced biomass and lipid content in the marine microalga Nannochloropsis sp. The combined stresses of light intensity and salinity, in the absence of nitrogen as the main building block, might induce severe oxidative damage to fatty acids, enzymes and re-channelling of carbon for osmoprotection 
and energy storage (Pal et al., 2011). Total lipid and fatty acid contents in Scenedesmus quadricauda and Tetraedron sp. were increased under combined effects of high salinity and nutrient limitation, but the combined factors had minimal effects on Desmodesmus armatus and Mesotaenium sp. (von Alvensleben et al., 2016). A starchless mutant strain of Chlamydomonas reinhardtii accumulated higher lipid content under nitrogen deprivation at a higher temperature of $32^{\circ} \mathrm{C}$ compared to its normal growth at $25^{\circ} \mathrm{C}$ (James et al., 2013). In contrast, a combined stress of temperature and nitrogen limitation in Nannochloropsis salina did not show remarkable difference in terms of lipid and triglyceride accumulation than nitrogen stress alone (Fakhry \& El Maghraby, 2015). The same genus Nannochloropsis sp. was treated with three parameters: salinity, light intensity and nitrogen availability in another study to compare its growth and lipid productivity. Triacylglycerol (TAG) accumulation was reported to be the highest under relatively high irradiance, nitrogenreplete and high salinity (Pal et al., 2011).

\section{CONCLUSION AND FUTURE DIRECTION}

This review provides an overview of the effects of multiple environmental drivers on microalgae. Most of the microalgal species are sensitive to abiotic stresses and able to acclimatize to various conditions. Changes in atmospheric $\mathrm{CO}_{2}$ level, temperature, irradiation, salinity and combination of these effects will affect relative abundance and distribution of the species. However, understanding intracellular changes caused by a single parameter might be inaccurate and insufficient to represent the complexity of the actual environment. It is important to understand how the interactive effects can be additive, synergistic, or antagonistic in affecting the growth of microalgae in response to climate change. Replicating the actual environment and designing a multifactorial studies to investigate the synergistic effects of various environmental factors remains a challenge. Future work should continue to provide a more holistic understanding on the impacts of climate change on microalgae and predict the climate-driven perturbations in the ecosystem.

\section{ACKNOWLEDGEMENTS}

This study was supported by HICoE MoHE: IOES-2014H grant, HICoE MOHE: IOES2014 (Air-ocean-land Interaction) grant, and UMCoE RU Grant: RU009-2015 and RU012-2016 (IOES).

\section{REFERENCES}

Affenzeller, MJ., Darehshouri, A., Andosch, A., Lütz, C., \& Lütz-Meindl, U. (2009). Salt stress-induced cell death in the unicellular green alga Micrasterias denticulata. Journal of Experimental Botany 60: 939-954.

An, M., Mou, S., Zhang, X., Ye, N., Cao, S., $\mathrm{Xu}$, D., Fan, X., Wang, Y., \& Miao, J. (2013). Temperature regulates fatty acid desaturases at a transcriptional level and modulates the fatty acid profile in the Antarctic microalga Chlamydomonas sp. ICE-L. Bioresource Technology 134: 151157.

Arbona, V., Manzi, M., Ollas, CD, \& GómezCadenas, A. (2013). Metabolomics as a tool to investigate abiotic stress tolerance in plants. International Journal of Molecular Sciences 14: 4885-4911.

Barcelos E Ramos, J., Müller, MN., \& Riebesell, U. (2010). Short-term response 
of the coccolithophore Emiliania huxleyi to an abrupt change in seawater carbon dioxide concentrations. Biogeosciences 7: 177-186.

Beardall, J., Stojkovic, S., \& Gao, K. (2014). Interactive effects of nutrient supply and other environmental factors on the sensitivity of marine primary producers to ultraviolet radiation: Implications for the impacts of global change. Aquatic Biology 22: 5-23.

BenMoussa-Dahmen, I., Chtourou, H., Rezgui, F., Sayadi, S., \& Dhouib, A. (2016). Salinity stress increases lipid, secondary metabolites and enzyme activity in Amphora subtropica and Dunaliella sp. for biodiesel production. Bioresource Technology 218: 816-825.

Bermúdez, R., Feng, Y., Roleda, MY., Tatters, AO., Hutchins, DA., Larsen, T., Boyd, PW., Hurd, CL., Riebesell, U., \& Winder, M. (2015). Long-term conditioning to elevated $\mathrm{pCO}_{2}$ and warming influences the fatty and amino acid composition of the diatom Cylindrotheca fusiformis. PloS One 10: e0123945.

Boyd, PW., Dillingham, PW., McGraw, CM., Armstrong, EA., Cornwall, CE., Feng, YY., Hurd, CL., Gault-Ringold, M., Roleda, MY., Timmins-Schiffman, E. \& Nunn, BL. (2015). Physiological responses of a Southern Ocean diatom to complex future ocean conditions. Nature Climate Change 6: 207-213.

Cao, K., He, M., Yang, W., Chen, B., Luo, W., Zou, S., \& Wang, C. (2016). The eurythermal adaptivity and temperature tolerance of a newly isolated psychrotolerant Arctic Chlorella sp. Journal of Applied Phycology 28: 877-888.

Carpenter, SR., Stanley, EH., \& Zanden, MJV. (2011). State of the world's freshwater ecosystems: Physical, chemical, and biological changes. Annual Review of Environment and Resources 36: 75-99.

Chankova, S., Mitrovska, Z., Miteva, D., Oleskina, YP., \& Yurina, NP. (2013). Heat shock protein HSP70B as a marker for genotype resistance to environmental stress in Chlorella species from contrasting habitats. Gene 516: 184-189.

Copia, J., Gaete, H., Zúñiga, G., Hidalgo, M., \& Cabrera, E. (2012). Effect of ultraviolet $B$ radiation on the production of polyphenols in the marine microalga Chlorella sp. Latin American Journal of Aquatic Research 40: 113-123.

D’ors, A., Bartolomé, MC., \& Sánchez-Fortún, S. (2016). Repercussions of salinity changes and osmotic stress in marine phytoplankton species. Estuarine, Coastal and Shelf Science 175: 169-175.

Darroch, LJ., Lavoie, M., Levasseur, M., Laurion, I., Sunda, WG., Michaud, S., Michaud, S., Scarratt, M., Gosselin, M., \& Caron, G. (2015). Effect of short-term light- and UV-stress on DMSP, DMS, and DMSP lyase activity in Emiliania huxleyi. Aquatic Microbial Ecology 74: 173-185.

Dickson, A. (2010). The carbon dioxide system in seawater: Equilibrium chemistry and measurements. In: Riebesell U., Fabry V.J., \& Hansson L. (eds.), Guide to best practices for ocean acidification research and data reporting, pp. 17-40, Luxembourg: Publications Office of the European Union.

Dingman, JE., \& Lawrence, JE. (2012). Heatstress-induced programmed cell death in Heterosigma akashiwo (Raphidophyceae). Harmful Algae 16: 108-116.

Doney, SC., Fabry, VJ., Feely, RA, \& Kleypas, JA. (2009). Ocean acidification: the other $\mathrm{CO}_{2}$ problem. Annual Review of Marine Science 1: 169-192. 
Durif, CMF., Fields, DM., Browman, HI., Shema, SD., Enoae, JR., Skiftesvik, AB., Bjelland, R., Sommaruga, R., \& Arts, M. (2015). UV radiation changes algal stoichiometry but does not have cascading effects on a marine food chain. Journal of Plankton Research 37: 1120-1136.

Eichner, M., Kranz, SA., \& Rost, B. (2014). Combined effects of different $\mathrm{CO}_{2}$ levels and $\mathrm{N}$ sources on the diazotrophic cyanobacterium Trichodesmium. Physiologia Plantarum 152: 316-330.

Einali, A., \& Valizadeh, J. (2015). Propyl gallate promotes salt stress tolerance in green microalga Dunaliella salina by reducing free radical oxidants and enhancing $\beta$-carotene production. Acta Physiologiae Plantarum 37: 1-11.

Endres, S., Unger, J., Wannicke, N., Nausch, M., Voss, M., \& Engel, A. (2013). Response of Nodularia spumigena to $\mathrm{CO}_{2}-$ Part 2: Exudation and extracellular enzyme activities. Biogeosciences 10: 567-582.

Engel, A. (2002). Direct relationship between $\mathrm{CO}_{2}$ uptake and transparent exopolymer particles production in natural phytoplankton. Journal of Plankton Research 24: 49-53.

Fakhry, EM., \& El Maghraby, DM. (2015). Lipid accumulation in response to nitrogen limitation and variation of temperature in Nannochloropsis salina. Botanical Studies 56: 6. http://doi.org/10.1186/s40529-0150085-7

Gao, K., Helbling, EW., Häder, DP., \& Hutchins, DA. (2012). Responses of marine primary producers to interactions between ocean acidification, solar radiation, and warming. Marine Ecology Progress Series 470: 167-189.

Garrido, J. L., Brunet, C., \& Rodríguez, F. (2016). Pigment variations in Emiliania huxleyi (CCMP370) as a response to changes in light intensity or quality. Environmental Microbiology. http://doi.org/10.1111/1462-2920.13373

Giovagnetti, V., Flori, S., Tramontano, F., Lavaud, J., \& Brunet, C. (2014). The velocity of light intensity increase modulates the photoprotective response in coastal diatoms. PLoS One 9: e0103782. http://doi.org/10.1371/journal.pone.010378 2

Goss, R., \& Jakob, T. (2010). Regulation and function of xanthophyll cycle-dependent photoprotection in algae. Photosynthesis Research 106: 103-122.

Gupta, B., \& Huang, B. (2014). Mechanism of salinity tolerance in plants: physiological, biochemical, and molecular characterization. International Journal of Genomics $\quad 2014$ : 701596. http://doi.org/10.1155/2014/701596

Ha, SY., Joo, HM., Kang, SH., Ahn, IY., \& Shin, KH. (2014). Effect of ultraviolet irradiation on the production and composition of fatty acids in plankton in a sub-Antarctic environment. Journal of Oceanography 70: 1-10.

Hughes, KA. (2006). Solar UV-B radiation, associated with ozone depletion, inhibits the Antarctic terrestrial microalga, Stichococcus bacillaris. Polar Biology 29: 327-336.

James, GO., Hocart, CH., Hillier, W., Price, GD., \& Djordjevic, MA. (2013). Temperature modulation of fatty acid profiles for biofuel production in nitrogen deprived Chlamydomonas reinhardtii. Bioresource Technology 127: 441-447.

Janknegt, PJ., De Graaff, CM., Van De Poll, WH., Visser, RJ., Helbling, EW., \& Buma, AG. (2009). Antioxidative responses of two marine microalgae during acclimation to 
static and fluctuating natural UV radiation. Photochemistry and Photobiology 85: 1336-1345.

Jin, P., Wang, T., Liu, N., Dupont, S., Beardall, J., Boyd, PW., Riebesell, U., \& Gao, K. (2015). Ocean acidification increases the accumulation of toxic phenolic compounds across trophic levels. Nature Communications $\quad 6: \quad 8714$. http://doi.org/10.1038/ncomms9714

Katayama, T., \& Taguchi, S. (2013). Photoprotective responses of an ice algal community in Saroma-Ko Lagoon, Hokkaido, Japan. Polar Biology 36: 14311439.

Kirrolia, A., Bishnoi, NR., \& Singh, N. (2011). Salinity as a factor affecting the physiological and biochemical traits of Scenedesmus quadricauda. Journal of Algal Biomass Utilization 2: 28-34.

Kobiyama, A., Tanaka, S., Kaneko, Y., Lim, P., \& Ogata, T. (2010). Temperature tolerance and expression of heat shock protein 70 in the toxic dinoflagellate Alexandrium tamarense (Dinophyceae). Harmful Algae 9: 180-185.

Kottmeier, DM., Rokitta, SD., Tortell, PD., \& Rost, B. (2014). Strong shift from $\mathrm{HCO}_{3}{ }^{-}$to $\mathrm{CO}_{2}$ uptake in Emiliania huxleyi with acidification: New approach unravels acclimation versus short-term $\mathrm{pH}$ effects. Photosynthesis Research 121: 265-275.

Krasensky, J., \& Jonak, C. (2012). Drought, salt, and temperature stress-induced metabolic rearrangements and regulatory networks. Journal of Experimental Botany 63: 1593-1608.

Langer, G., \& Bode, M. (2011). $\quad \mathrm{CO}_{2}$ mediation of adverse effects of seawater acidification in Calcidiscus leptoporus. Geochemistry Geophysics Geosystems 12: 1-8.
Légeret, B., Schulz-Raffelt, M., Nguyen, HM., Auroy, P., Beisson, F., Peltier, G., Blanc, G., \& Li-Beisson, Y. (2016). Lipidomic and transcriptomic analyses of Chlamydomonas reinhardtii under heat stress unveil a direct route for the conversion of membrane lipids into storage lipids. Plant, Cell and Environment 39: 834-847.

Lepetit, B., Goss, R., Jakob, T., \& Wilhelm, C. (2012). Molecular dynamics of the diatom thylakoid membrane under different light conditions. Photosynthesis Research 111: 245-257.

Levitan, O., Rosenberg, G., Setlik, I., Setlikova, E., Grigel, J., Klepetar, J., Prasil, O., \& Berman-Frank, I. (2007). Elevated $\mathrm{CO}_{2}$ enhances nitrogen fixation and growth in the marine cyanobacterium Trichodesmium. Global Change Biology 13: 531-538.

Li, W., Xu, X., Fujibayashi, M., Niu, Q., Tanaka, N., \& Nishimura, O. (2016). Response of microalgae to elevated $\mathrm{CO}_{2}$ and temperature: impact of climate change on freshwater ecosystems. Environmental Science and Pollution Research 23: 1984719860. http://doi.org/10.1007/s11356-0167180-5

Lu, N., Wei, D., Chen, F., \& Yang, ST. (2012). Lipidomic profiling and discovery of lipid biomarkers in snow alga Chlamydomonas nivalis under salt stress. European Journal of Lipid Science and Technology 114: 253265.

Lukeš, M., Procházková, L., Shmidt, V., Nedbalová, L., \& Kaftan, D. (2014). Temperature dependence of photosynthesis and thylakoid lipid composition in the red snow alga Chlamydomonas cf. nivalis (Chlorophyceae). FEMS Microbiology Ecology 89: 303-315.

Lyon, B., \& Mock, T. (2014). Polar microalgae: New approaches towards 
understanding adaptations to an extreme and changing environment. Biology 3: 5680.

Ma, R., Lu, F., Bi, Y., \& Hu, Z. (2015). Effects of light intensity and quality on phycobiliprotein accumulation in the cyanobacterium Nostoc sphaeroides Kützing. Biotechnology Letters 37: 16631669.

McGinty, ES., Pieczonka, J., \& Mydlarz, LD. (2012). Variations in reactive oxygen release and antioxidant activity in multiple Symbiodinium types in response to elevated temperature. Microbial Ecology 64: 10001007.

Meier, KJS., Beaufort, L., Heussner, S., \& Ziveri, P. (2014). The role of ocean acidification in Emiliania huxleyi coccolith thinning in the Mediterranean Sea. Biogeosciences 11: 2857-2869.

Meneghesso, A., Simionato, D., Gerotto, C., la Rocca, N., Finazzi, G., \& Morosinotto, T. (2016). Photoacclimation of photosynthesis in the Eustigmatophycean Nannochloropsis gaditana. Photosynthesis Research 129: 115.

Meyer, J., \& Riebesell, U. (2015). Reviews and syntheses: Responses of coccolithophores to ocean acidification: A meta-analysis. Biogeosciences 12: 16711682.

Milledge, JJ. (2011). Commercial application of microalgae other than as biofuels: a brief review. Reviews in Environmental Science and Biotechnology 10: 31-41.

Nahon, S., Charles, F., Lantoine, F., Vétion, G., Escoubeyrou, K., Desmalades, M., \& Pruski, AM. (2010). Ultraviolet radiation negatively affects growth and food quality of the pelagic diatom Skeletonema costatum. Journal of Experimental Marine Biology and Ecology 383: 164-170.
Newbold, LK., Oliver, AE., Booth, T., Tiwari, B., Desantis, T., Maguire, M., Andersen, G., van der Gast, CJ., \& Whiteley, AS. (2012). The response of marine picoplankton to ocean acidification. Environmental Microbiology 14: 2293-2307.

Norici, A., Bazzoni, AM., Pugnetti, A., Raven, JA., \& Giordano, M. (2011). Impact of irradiance on the $\mathrm{C}$ allocation in the coastal marine diatom Skeletonema marinoi Sarno and Zingone. Plant, Cell and Environment 34: 1666-1677.

Pachauri, RK., Allen, MR., Barros, VR., Broome, J., Cramer, W., Christ, R., Church, JA., Clarke, L., Dahe, Q., Dasgupta, P., Dubash, NK., Edenhofer, O., Elgizouli, I.,Field, CB.,Forster, P., Friedlingstein, P., Fuglestvedt, J., GomezEcheverri, L., Hallegatte, S., Hegerl, G., Howden, M., Jiang, K., Jimenez Cisneroz, B., Kattsov, V., Lee, H., Mach, KJ., Marotzke J., Mastrandrea, MD., Meyer, L., Minx, J., Mulugetta, Y., O'Brien, K., Oppenheimer, M., Pereira, JJ., PichsMadruga, R., Plattner, GK., Pörtner, HO., Power, SB., Preston, B.,Ravindranath, NH., Reisinger, A., Riahi, K., Rusticucci, M., Scholes, R., Seyboth, K., Sokona, Y., Stavins, R., Stocker, TF., Tschakert, P., van Vuuren, D. and van Ypserle, JP. (2014). Climate change 2014: Synthesis report. Contribution of working groups I, II and III to the fifth assessment report of the intergovernmental panel on climate change, pp. 151, Intergovenmental Panel of Climate Change (IPCC).

Pal, D., Khozin-Goldberg, I., Cohen, Z., \& Boussiba, S. (2011). The effect of light, salinity, and nitrogen availability on lipid production by Nannochloropsis sp. Applied Microbiology and Biotechnology 90: 14291441.

Pancha, I., Chokshi, K., Maurya, R., Trivedi, K., Patidar, SK., Ghosh, A., \& Mishra, S. 
(2015). Salinity induced oxidative stress enhanced biofuel production potential of microalgae Scenedesmus sp. CCNM 1077. Bioresource Technology 189: 341-348.

Prowse, TD., Wrona, FJ., Reist, JD., Gibson, JJ., Hobbie, JE., Lévesque, LMJ., \& Vincent, WF. (2006). Climate change effects on hydroecology of Arctic freshwater ecosystems. AMBIO: A Journal of the Human Environment 35: 347-358.

Raven, JA., Giordano, M., Beardall, J., \& Maberly, SC. (2012). Algal evolution in relation to atmospheric $\mathrm{CO}_{2}$ : carboxylases, carbon-concentrating mechanisms and carbon oxidation cycles. Philosophical Transactions of the Royal Society B 367: 493-507.

Rivas, C., Navarro, N., Huovinen, P., \& Gómez, I. (2016). Photosynthetic UV stress tolerance of the Antarctic snow alga Chlorella sp. modified by enhanced temperature? Revista Chilena de Historia Natural 89: 7. http://doi.org/10.1186/s40693-016-0050-1

Rossoll, D., Bermúdez, R., Hauss, H., Schulz, KG., Riebesell, U., Sommer, U., \& Winder, M. (2012). Ocean acidification-induced food quality deterioration constrains trophic transfer. PLoS One 7: e0034737. http://doi.org/10.1371/journal.pone.003473 7

Ryther, JH., \& Menzel, DW. (1959). Light adaptation by marine phytoplankton. Limnology and Oceanography 4: 492-497.

Salama, ES., \& Kim, HC. (2013). Biomass, lipid content, and fatty acid composition of freshwater Chlamydomonas mexicana and Scenedesmus obliquus grown under salt stress. Bioprocess and Biosystems Engineering 36: 827-833.

Schroda, M., Hemme, D., \& Mühlhaus, T. (2015). The Chlamydomonas heat stress response. The Plant Journal: For Cell and Molecular Biology 82: 466-480.

Schulz, KG., Bellerby, RGJ., Brussaard, CPD., Büdenbender, J., Czerny, J., Engel, A., Fischer, M., Koch-Klavsen, S., Krug, SA., Lischka, S., Ludwig, A., Meyerhöfer, M., Nondal, G., Silyakova, A., Stuhr, A., \& Riebesell, U. (2013). Temporal biomass dynamics of an Arctic plankton bloom in response to increasing levels of atmospheric carbon dioxide. Biogeosciences 10: 161-180.

Singh, SP., \& Singh, P. (2014). Effect of $\mathrm{CO}_{2}$ concentration on algal growth: A review. Renewable and Sustainable Energy Reviews 38: 172-179.

Smirnoff, N. (1995). Metabolic flexibility in relation to the environment. In: N. Smirnoff (Ed.), Environment and Plant Metabolism: Flexibility and Acclimation, pp. 1-16, Oxford: BIOS Scientific Publishers.

Steinacher, M., Joos, F., Frölicher, TL., Plattner, GK., \& Doney, SC. (2009). Imminent ocean acidification in the Arctic projected with the NCAR global coupled carbon cycle-climate model. Biogeosciences 6: 515-533.

Suffrian, K., Schulz, KG., Gutowska, MA., Riebesell, U., \& Bleich, M. (2011). Cellular $\mathrm{pH}$ measurements in Emiliania huxleyi reveal pronounced membrane proton permeability. New Phytologist 190: 595608.

Sun, J., Hutchins, DA., Feng, YY., Seubert, E. L., Caron, DA., \& Fu, FX. (2011). Effects of changing $\mathrm{pCO}_{2}$ and phosphate availability on domoic acid production and physiology of the marine harmful bloom diatom Pseudo-nitzschia multiseries. Limnology and Oceanography 56: 829-840.

Teoh, ML., Chu, WL., Marchant, H., \& Phang, SM. (2005). Influence of culture 
temperature on the growth, biochemical composition and fatty acid profiles of six Antarctic microalgae. Journal of Applied Phycology 2: 421-430.

Teoh, ML., Phang, SM., \& Chu, WL. (2013). Response of Antarctic, temperate, and tropical microalgae to temperature stress. Journal of Applied Phycology 25: 285-297.

Torstensson, A., Chierici, M., \& Wulff, A. (2012). The influence of increased temperature and carbon dioxide levels on the benthic/sea ice diatom Navicula directa. Polar Biology 35: 205-214.

Torstensson, A., Hedblom, M., Andersson, J., Andersson, MX., \& Wulff, A. (2013). Synergism between elevated $\mathrm{pCO}_{2}$ and temperature on the antarctic sea ice diatom Nitzschia lecointei. Biogeosciences 10: 6391-6401.

Varshney, P., Mikulic, P., Vonshak, A., Beardall, J., \& Wangikar, PP. (2015). Extremophilic micro-algae and their potential contribution in biotechnology. Bioresource Technology 184: 363-372.

von Alvensleben, N., Magnusson, M., \& Heimann, K. (2016). Salinity tolerance of four freshwater microalgal species and the effects of salinity and nutrient limitation on biochemical profiles. Journal of Applied Phycology 28: 861-876.

Wilby, RL., Orr, H., Watts, G., Battarbee, RW., Berry, PM., Chadd, R., Dugdale, SJ., Dunbar, MJ., Elliott, JA., Extence, C., Hannah, DM., Holmes, N., Johnson, AC., Knights, B., Milner, NJ., Ormerod, SJ., Solomon, D., Timlett, R., Whitehead, PJ., \& Wood, PJ. (2010). Evidence needed to manage freshwater ecosystems in a changing climate: Turning adaptation principles into practice. Science of the Total Environment 408: 4150-4164.

Wong CY., Teoh ML., Phang SM. \& Chu WL.
(2011). Effect of ultraviolet radiation (UVR) on the tropical microalgae Chlorella vulgaris. Malaysian Journal of Science 30: 3-15.

Wong, CY., Teoh, ML., Phang, SM., Lim, PE., \& Beardall, J. (2015). Interactive effects of temperature and UV radiation on photosynthesis of Chlorella strains from polar, temperate and tropical environments: Differential impacts on damage and repair. PloS One 10: e0139469. http://doi.org/10.1371/journal.pone.013946 9

Wong, JCF., \& Parisi, AV. (1999) Assessment of ultraviolet radiation exposures in photobiological experiments. In: Proceedings of the 2nd Internet Photochemistry and Photobiology Conference, 16 July - 7 September, pp. 119, Internet Photochemistry and Photobiology.

Wu, Y., Gao, K., \& Riebesell, U. (2010). $\mathrm{CO}_{2-}$ induced seawater acidification affects physiological performance of the marine diatom Phaeodactylum tricornutum. Biogeosciences 7: 2915-2923.

Yang, G., \& Gao, K. (2012). Physiological responses of the marine diatom Thalassiosira pseudonana to increased $\mathrm{pCO}_{2}$ and seawater acidity. Marine Environmental Research 79: 142-151.

Yang, S., Jin, W., Wang, S., Hao, X., Yan, Y., Zhang, M., \& Zheng, B. (2015). Chlorophyll ratio analysis of the responses of algae communities to light intensity in spring and summer in Lake Erhai. Environmental Earth Sciences 74: 38773885 .

Zeebe, RE., Ridgwell, A., \& Zachos, JC. (2016). Anthropogenic carbon release rate unprecedented during the past 66 million 
years. Nature Geoscience 9: 325-329.

Zhang, Y., Bach, LT., Schulz, KG., \& Riebesell, U. (2015). The modulating effect of light intensity on the response of the coccolithophore Gephyrocapsa oceanica to ocean acidification. Limnology and Oceanography 60: 2145-2157.

Zhila, NO., Kalacheva, GS., \& Volova, TG. (2011). Effect of salinity on the biochemical composition of the alga Botryococcus braunii Kütz IPPAS H-252.
Journal of Applied Phycology 23: 47-52.

Zidarova, R., \& Pouneva, I. (2006). Physiological and biochemical characterization of antarctic isolate Choricystis minor during oxidative stress at different temperatures and light intensities. General and Applied Plant Physiology Special Issue: 109-115. 